\title{
Sedimentology of the Psammo-pelitic-carbonate Unit, Paranoá Group, and Sete Lagoas Formation, Bambuí Group: examples of mixed carbonate- siliciclastic sedimentation in the Proterozoic of the Brasília Fold Belt
}

\author{
José Eloi Guimarães Campos ${ }^{1 *}$, Jéssica Bogossian ${ }^{1}$, Rômulo Mendes Carvalho ${ }^{1}$
}

\begin{abstract}
The mixed carbonate-siliciclastic platforms are still poorly studied, although they represent important regional sedimentary successions in the Brasília Fold Belt. The aim of the present paper was to determine the deposition conditions of the Psammo-pelitic-carbonate Unit (top of the Paranoá Group) and the Sete Lagoas Formation (base of the Bambuí Group) in the Brasília Fold Belt, central Brazil. The sedimentation of the two sequences occurred in a mixed platform controlled by the bottom paleogeography where carbonate facies were deposited in shallow environment and detrital facies in deeper water. In the Paranoá Group, small limestone and dolomite lenses are found in the highest areas, whereas pelites were deposited in depressions and psammites inplatform channels. In the Sete Lagoas Formation, the major carbonate lenses were deposited over the highs derived from the post-glacial erosion surface that marks the unconformity between the Paranoá and Bambuí groups. In both units, micritic mud predominates, and reworking by waves occurred sporadically and associated with progradationretrogradation. The aggradation of terrigenous material caused deposition of pelitic facies. The dimensions, thickness, and distribution of carbonate lenses show that the paleorelief was more pronounced during the deposition of the Sete Lagoas Formation, when compared with the Psammo-Pelitic-Carbonate Unit. On the other hand, the sedimentation rate of Psammo-Pelitic-Carbonate Unit was greater than the one of the Sete Lagoas Formation.
\end{abstract}

Keywords: Carbonate-siliciclastic platform; Bambuí Group; Paranoá Group.

Resumo Sedimentologia da Unidade Psamo-pelito-carbonatada, Grupo Paranoá e da Formação Sete Lagoas, Grupo Bambuí: exemplos de sedimentação mista carbonática-siliciclástica no Proterozoico da Faixa Brasília. Apesar de muito importantes e de ocorrerem em várias sucessões litoestratigráficas na Faixa Brasília, as plataformas mistas de sedimentação silicilástica-carbonática ainda são pouco estudadas. O presente trabalho objetivou a determinação das condições deposicionais da unidade de topo do Grupo Paranoá (Unidade Psamo-Pelito-Carbonatada) e da Formação Sete Lagoas (base do Grupo Bambuí) na Faixa Brasília. A sedimentação das duas sucessões se deu em uma plataforma mista controlada pela paleogeografia de fundo em que as fácies carbonáticas foram depositadas em águas mais rasas e apenas ocasionalmente mais agitadas e as fácies terrígenas ocupavam as águas mais profundas. No Grupo Paranoá, as pequenas lentes de calcário e dolomito ocupavam as áreas mais elevadas, enquanto os pelitos se depositavam nas depressões e os psamitos correspondem aos canais na plataforma. Na Formação Sete Lagoas, a deposição das maiores lentes de rochas carbonáticas se dava sobre as elevações herdadas da superfície erosiva pós-glacial que marca a discordância entre os grupos Paranoá e Bambuí. Nas duas unidades, o processo de precipitação de lamas micríticas foi predominante nas fácies carbonáticas, enquanto o retrabalhamento por base de ondas ocorria de forma esporádica e associado a movimentos progradacionais/retrogradacionais. A agradação de lamas terrígenas foi o processo responsável pela sedimentação das fácies pelíticas. As dimensões, espessuras e distribuição das lentes de rochas carbonáticas mostram que o paleo relevo era mais acentuado durante a deposição da Formação Sete Lagoas, se comparado à Unidade Psamo-Pelito-Carbonatada. Por outro lado, a taxa de sedimentação foi maior durante a deposição da Unidade Psamo-Pelito-Carbonatada que na Formação Sete Lagoas.

Palavras-chave: Plataforma carbonática-siliciclástica; Grupo Bambuí; Grupo Paranoá.

INTRODUCTION The main controls of the carbonate deposition are the existence of clean and warm water and the absence of terrigenous material, since the input of terrigenous material results in a decrease in organic production and, consequently, a decrease in sedimentation of carbonate rocks. In other words, the carbonate sedimentation is inhibited by an increase in the proportion of terrigenous material in the basin.

However, mixed sedimentation in carbonate-siliciclastic platforms is quite usual in the geological record, differently from what is

'Institute of Geosciences, Universidade de Brasília - UnB, Brasília (DF), Brasil. E-mail: eloi@unb.br, jessicabogossian@gmail.com, romulomc@gmail.com

*Corresponding author 
described in the classic literature. In Brazil, many examples of mixed depositional system can be offered, particularly in the Proterozoic sedimentary successions of the Brasília Fold Belt, where at least four important successions can be listed: top of the Araí depositional sequence (Martins 1999), middle and top of the sedimentary succession of the Paranoá Group (Faria 1995), part of the stratigraphy of the Vazante Group (Dardenne 2000) and the entire basal section of the Bambuí Group (Dardenne 1978, 1979).

With this considered, the objective of this paper was to study the Psammo-pelitic-carbonate Unit of the Paranoá Group and the Sete Lagoas Formation of the Bambuí Group in the Brasília Belt, as well as to determine the controls and mechanisms of simultaneous deposition of terrigenous and carbonate sediments.

The study area is located in the northwestern part of the Federal District and extends to the north of the Goiás state, including the exposures at the base of the Bambuí Group over the São Francisco Craton.

This study is important because, although mixed carbonate-siliciclastic sedimentation is very common in the Brasília Belt, the controls of this sedimentation and of the environments and depositional processes related to this sedimentation are poorly studied. Only the study by Laranjeira (1992) aimed at studying specifically the mixed platform of the Paranoá sequence in the Unaí region, Minas Gerais state.

\section{MIXED CARBONATE-SILICICLASTIC} SEDIMENTATION The simultaneous deposition of carbonate and siliciclastic sediments occurs under different water depth conditions, under contrasting tectonic conditions, in distinct chronostratigraphic periods (from the Proterozoic to the Phanerozoic), under different energy deposition conditions and by different depositional processes (suspension, traction, detrital flux, organic building, and chemical precipitation).

Other important difference is that terrigenous sediments are produced by weathering and erosion of the source area, which are after transported to the depositional basin and deposited in different environments. The material that forms carbonate layers is produced in the depositional basin itself and is in great part controlled by biological activity (direct carapace accumulation or microorganism and invertebrate metabolism).

The metabolism of animals with carbonate exoskeleton is considered the main source of material supply to the Phanerozoic carbonate successions. In general, these carbonates can be considered as product of direct accumulation of carapace fragments (bioclastic grainstones and packstones) or as formed from micritic muds produced by organic activity (bioclastic and peloidal mudstones and wackstones). In addition to these carbonate rocks, there are those formed by reworking of carbonates previously deposited in the basin within short transport distances and with small movement in the platform (intraclastic grainstones and packstones or intraclastic rudstones and floatstones).

On the other hand, the main control of Proterozoic carbonates is related to the activity of algae and cyanobacteria with production of micritic mud and formation of mudstone and rocks rich in carbonate fragments (intraclastic floatstones and packstones) and, in small proportion, carbonates with ooids (oncolites and oolites).

In mixed carbonate-terrigenous platforms, carbonates are laterally and vertically intercalated with pelites, psammites and even conglomerates, and the facies in the intercalation zones are commonly represented by marls (impure limestones or calciferous detrital rocks).

The main parameters that determine the deposition of the carbonate-siliciclastic sequences are:

- position of the photic zone in the ramp-type platform;

- $\quad$ paleogeography with basement highs;

- $\quad$ existence of protected parts within the depositional system in zoned platforms;

- chemical control of sedimentation with bicarbonate and calcium saturation that allows the direct deposition of carbonate from the sea water under favorable physicochemical conditions.

The model of carbonate-siliciclastic ramp is a type of control that has already been described by several authors (such as Khetani \& Read 2002), in which the production of carbonate material and its deposition are related to the conditions of maximum organic production in 
the photic zone under favorable conditions of bottom topography during a period of tectonic stability.

A detailed description of the development of a mixed platform under control of active tectonics during sedimentation was given by Cózar et al. (2006). In this case, the controls include water turbidity, subsidence, siliciclastic discharge and storm events. The tectonics related to dipslip normal fault is responsible for delimiting the blocks in which carbonate deposition is favored and for laterally interruption of facies. Dorsey \& Kidwell (1999) also described mixed sedimentation in active margins.

Mixed deposition can occur in different tectonic contexts, varying from stable conditions, such as passive margins, to environments associated with rift phase of basins with active subsidence.

Carbonate facies intercalated with terrigenous sediments also occur under different water temperature conditions and have been found even in glacial environments as part of intercalations of bioclastic limestones with glaciogenic rudites .

Fig. 1, briefly and schematically, shows the main types of tectonic environments and platforms in which mixed sedimentation occurs. The macro-controls of simultaneous sedimentation of carbonate and siliciclastics include: paleogeography of the basin basement, eustatic variations on different time scales, syn-depositional tectonics, and photic zone position and distribution.

Regardless of the deposition site, simultaneous sedimentation of carbonates and terrigenous needs that, at least in localized parts, the conditions that favored the calcium carbonate precipitation are met. The main conditions are: cleaner water (small amount of detritus), warmer water, lighter environment (associated with the photic zone), greater nutrient availability (for favoring organic development) and more stable water composition.

Faciology of carbonate successions associated with mixed platforms shows that limestones can be deposited by distinct processes in different environments, varying from inner parts of platforms and deltaic transitional facies, tidally dominated (Spalletti et al. 2000), to outer parts of platforms under storm conditions (Rowe 2002).

\section{REGIONAL GEOLOGICAL CONTEXT}

Paranoá Group The Paranoá Group is a Psammopelitic-carbonate sequence with wide distribution to the north of the Federal District. Its type locality and the holostratotypes of its units were defined by Faria (1995) in the region of Alto Paraíso de Goiás, São João D'Aliança (Fig. 2). It is a succession of passive margin with eleven distinct units, which constitute different compartments with deposition conditions that varies from supra-tidal, through coastal conditions, to storm-dominated platforms.

Lithofaciology shows that the areas outside the basin possibly represented by sialic basement have high relief, providing a continuous supply of psammitic terrigenous sediments.

This succession shows faciological variations when comparing different areas of occurrence, such as the region of Cabeceiras (MG), where an important arkose layer occurs at the top (Guimarães 1997), and the region of Quebra Linha (GO) (Fuck et al. 1988), where at least three units with several carbonate lenses occur. However, in all distribution areas, this unit has important occurrences of carbonate rocks (metalimestones, metadolomites and metamarls) in the middle of the stratigraphic column and more prominently at the top.

Carbonates occur as lenses ranging from a few meters to a few hundred meters, with different internal faciology, but always with coarse to very coarse sand facies and predominance of micritic facies.

The occurrence of conical stromatolites of Conophyton Metula Kirichenko type indicates an age between 1,350 and $950 \mathrm{Ma}$ (Dardenne, Melo \& Moeri 1972), which includes the time interval between the end of deposition of the Araí Group and the beginning of deposition of the Bambuí Group.

Bambuí Group The Bambuí Group, which is an arkose-carbonate-pelite succession, occurs along the entire outer part of the Brasília Belt and is part of the vast Neoproterozoic cover of the São Francisco Craton.

The stratigraphic column proposed by Dardenne (1978) can be observed in almost all areas where the Bambuí succession occurs (Fig. 3). However, when there is no key bed of carbonate and 
A

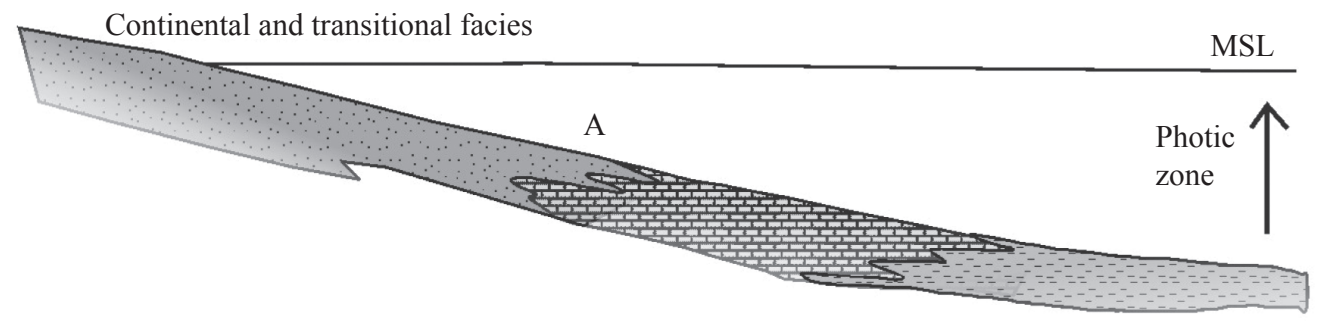

B

Continental and transitional facies

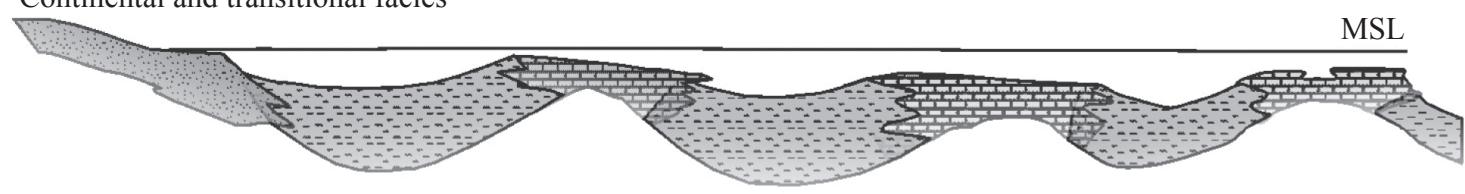

C

MSL

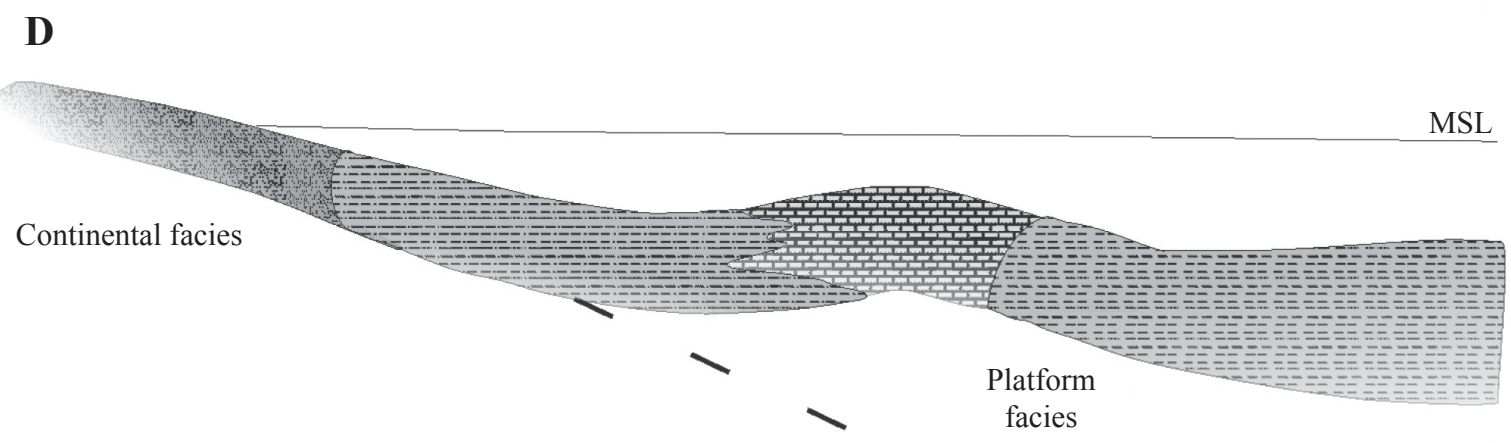

$\mathbf{E}$

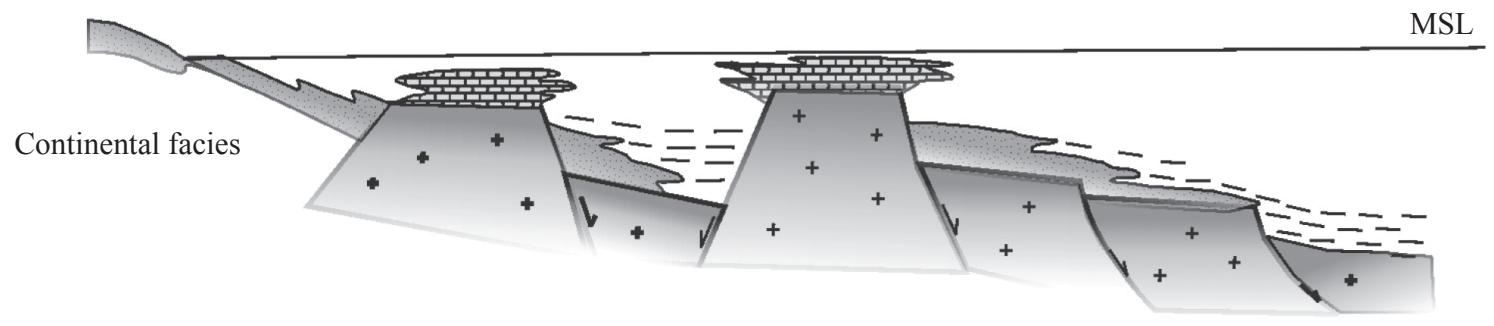

Figure 1 - (A) Carbonate-siliciclastic ramp controlled by the photic zone in clean water of the outer part of the platform, where the input of terrigenous is limited; (B) Mixed platform controlled by the paleogeography, which makes possible the presence of warm, clean, shallow water side by side with deeper water, where terrigenous deposition occurs; (C) Carbonate turbidite platform with intercalation of sandy clastic facies with pelitic facies; (D) Mixed platform with deposition of oolitic limestone bars with terrigenous resulting from the dynamics of eustatic rising and lowering of sea level, and (E) Mixed sedimentation controlled by block tectonics, which makes possible the presence of deep waters side by side with shallow waters. 


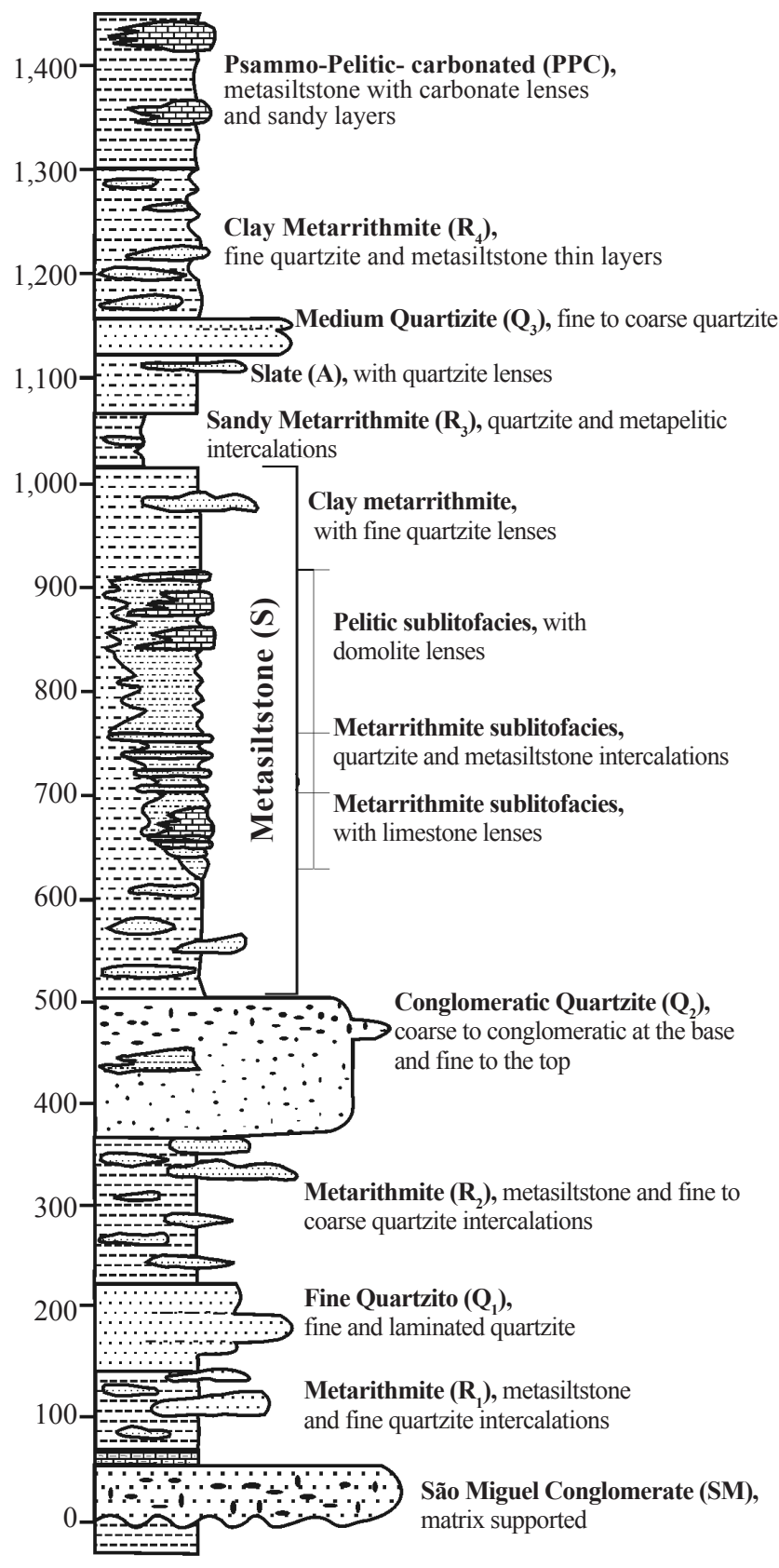

\begin{tabular}{|c|c|c|c|c|}
\hline & & & & \\
A & $\mathbf{S}$ & AF & AM AG C
\end{tabular}

Figure 2 - Stratigraphy of the Paranoa Group in the type locality of Alto Paraíso de Goiás, São João D'Aliança (according to Faria 1995).

arkose rocks, but only pelites, the stratigraphic positioning becomes difficult.

The nature of the sediments of the outer part of the Brasília Belt shows that the relief of the source area was worn down and had a gentle gradient, due to great predominance of pelites and absence of sand. Sand fraction occurs only at the top of this succession, which is represented by arkoses

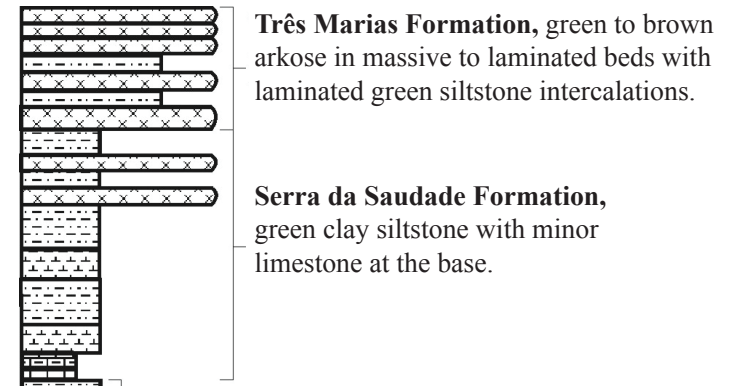

Lagoa do Jacaré Formation, clay siltitstone intercalated with oolitic limestone lenses.

Serra de Santa Helena Formation, argilite with minor limestone lenses and localy very fine sand beds.

Sete Lagoas Formation, siltstone at the base with laminated dolomite lenses. To the top there are brecciated and oolitic limestone facies.

Jequitaí Formation, polimitic matrix supported conglomerate (glacigenic diamictite).

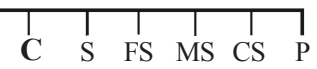

Figure 3 - Stratigraphy of Bambui Group (according to Dardenne 1978).

and greywackes of the Três Marias Formation, whose deposition is attributed to the relief produced by the mountain ranges related to the first nappes formed during the development of the Brasília Fold Belt.

There has been controversy over the age of deposition of the Bambuí Group. However, its stratigraphic position and unconformity with the top of the Paranoá Group, as well as isotopic studies, indicate a Neoproterozoic age for this group.

Freitas-Silva (1996) carried out a critical analysis, made a new interpretation of the available geochronological data, and proposed the age of $762 \pm 49 \mathrm{Ma}$ for the sedimentation and $547 \pm 57 \mathrm{Ma}$ for the interpreted age associated with an homogenization event, possibly resulting from processes of diagenetic and metamorphic recrystallization. 


\section{DETRITAL CARBONATE UNITS}

Top of the Paranoá Group The Psammo-peliticcarbonate Unit of the Paranoá Group has a transitional contact with the underlying unit and is marked by a progressive increase in meta-argillites when compared with quartzites and metasiltstones. This unit is widespread in the north of the Federal District and extends continuously towards the north of the Goiás state (Freitas-Silva \& Campos 1998).

Lithologically, it is mainly represented by siltic metamudstones, which are silver gray (and changes to yellow or pinkish due to alteration), very laminated, and occasionally have a foliation and silky texture due to the abundance of phyllosilicates. The lithological types previously mentioned are the most common in this unit, amounting to approximately $85 \%$ of the succession.

The quartzites of this succession occur as elongated lenses, ranging from a few meters to tens of meters, or as laterally continuous centimetric levels. They are medium, coarse-grained to conglomeratic feldspathic quartzites, poorly sorted, black to dark gray (due to an organic pellicle surrounding the detrital grains), with sub-angular to rounded fragments. This lithological type is not common in outcrops, since they are easily disaggregated. However, they are very frequent in drill cuttings of deep tubular wells. Sometimes, quartzites and fine-grained conglomerates have a pinkish or ochre pelitic matrix. Analyses of thin sections show rounded quartz and angular feldspar grains with plane to sutured contacts, where microcline greatly predominates over plagioclase.

Carbonate facies that occur strongly interfingered with pelitic and quartzitic rocks are represented by micritic or intraclastic black or dark gray limestones (classified as mudstones and intraclastic grainstones, packstones and floatstones) and subordinately by locally stromatolitic light gray dolomites. The stromatolite shape is conical or columnar, in addition to horizontal or dome shape stromatolitic mats. The columnar stromatolites are more abundant (Fig. 4). In these carbonates, stromatolites are less abundant than in the Bambuí Group.

The lenticular geometry of the carbonate facies is easily interpreted based on the pattern of the outcrops that show clear intercalation with pelites. The lens diameter varies from hundred of meters to more than one kilometer. Commonly, limestones and dolomites show thin lamination and layers of clay material marking the primary bedding. Silicified limestone breccias are distributed with no stratigraphic control, and are found near the margins of some lenses or in lower topographic positions, possibly at the base of carbonate cycles (Fig. 5). In the

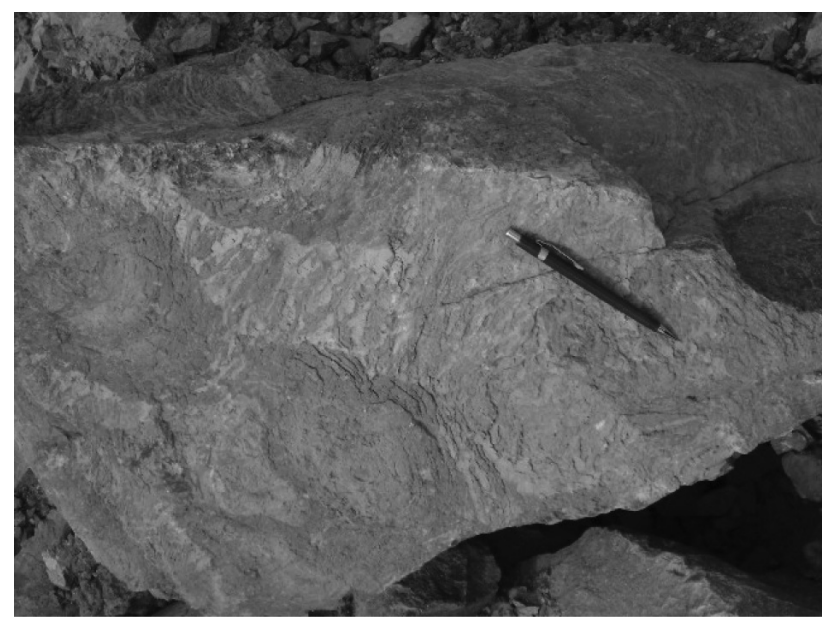

Figure 4 - Columnar stromatolite in dolomite. Note the coarse-grained facies composed of intraclastic floatstone which constitutes the intercolumnar material.

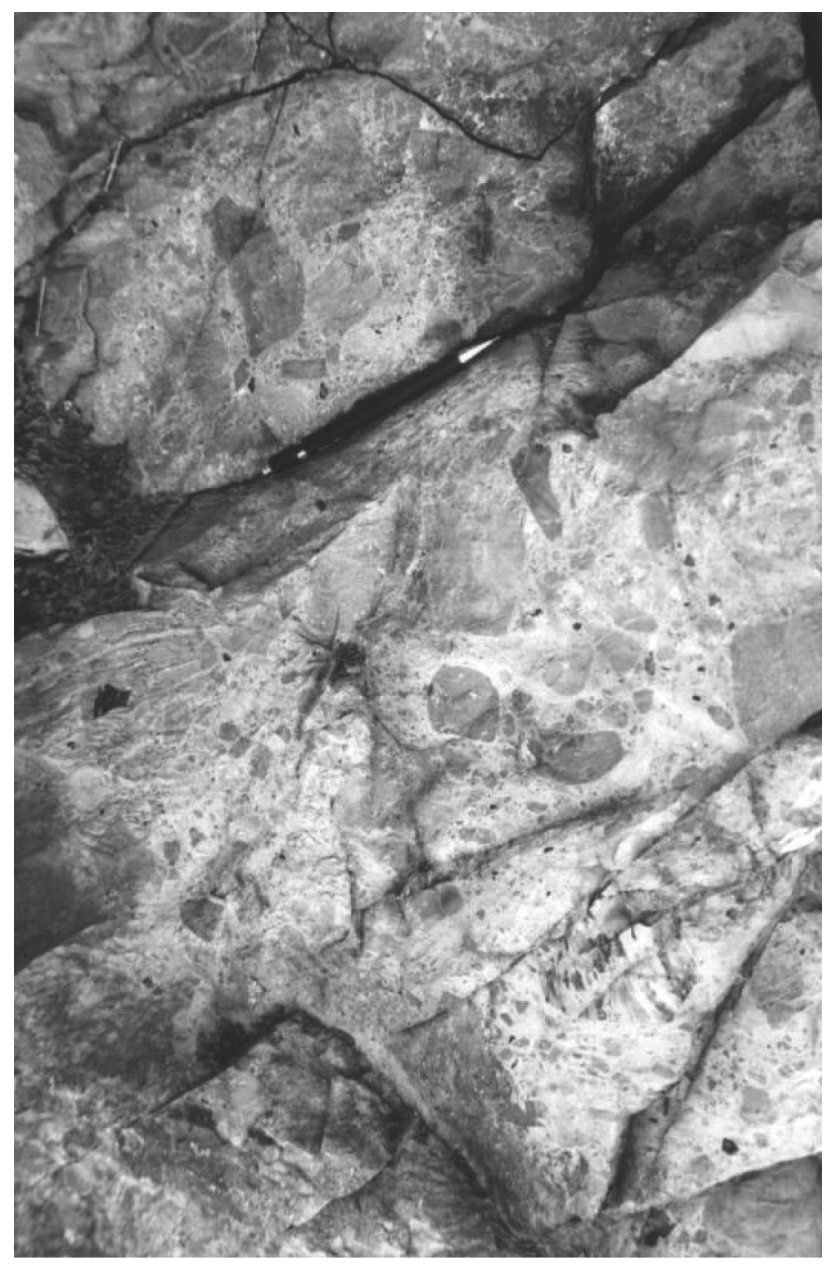

Figure 5 - Facies of dolomitized breccia. 
zone of intercalation of carbonate lenses with pelitic rocks, metamarl facies are common with massive aspect when fresh, and porous aspect when weathered.

It is important to highlight that the occurrences of psammites and psephites in this unit are usually limited in area, amounting to only approximately $5 \%$, and these rocks can be found in any stratigraphic position. However, this coarse material is used as a marker and parameter for distinguishing this unit from the carbonate facies of the overlying Bambui Group.

Bottom of the Bambuí Group: The basal unit of the Bambuí Group occurs in the north of the Federal District and is more continuous along the margins of the São Francisco Craton. This unit is predominantly composed of pelitic material, laterally and vertically interbedded with lenses of carbonate rocks.

Pelites represented by shales and argillaceous siltstones constitute the most common facies. These laminated rocks are green to dark gray when fresh and light green, yellow, pinkish and red when weathered. The carbonate facies are mainly represented by massive or stratified micritic limestones (mudstones), with occasional occurrence of calcarenites (intraclastic and oncolitic grainstones and packstones) and calcirudites (intraclastic floatstones) (Fig. 6). In the transition facies between carbonate lenses and pelitic facies, there is a rhythmite characterized by regular intercalation of layers (from 0.5 to $1.5 \mathrm{~cm}$ ) of pure micritic limestones with pelitic marls (Fig. 7). Dolomite facies with columnar stromatolites occur locally. Gray limestones are the most common, and layers of purple limestones can also be found.

Facies of shallow to very shallow water are characterized by carbonates with organosedimentary structures characterized as columnar stromatolites and by mud cracks (Fig. 8), which indicate sub-aerial exposure. These structures and the general faciology of the carbonate lenses indicate that the sedimentation occurred in shallower water, whereas the pelitic material indicates that the sedimentation occurred by vertical aggradation in deeper waters.

The lenses of carbonate rocks of this group are larger than those found in the Paranoá Group and are often continuous for up to $4 \mathrm{~km}$. In the Água Fria region (GO), there is a continuous lens, measuring $12 \times 4 \mathrm{~km}$.

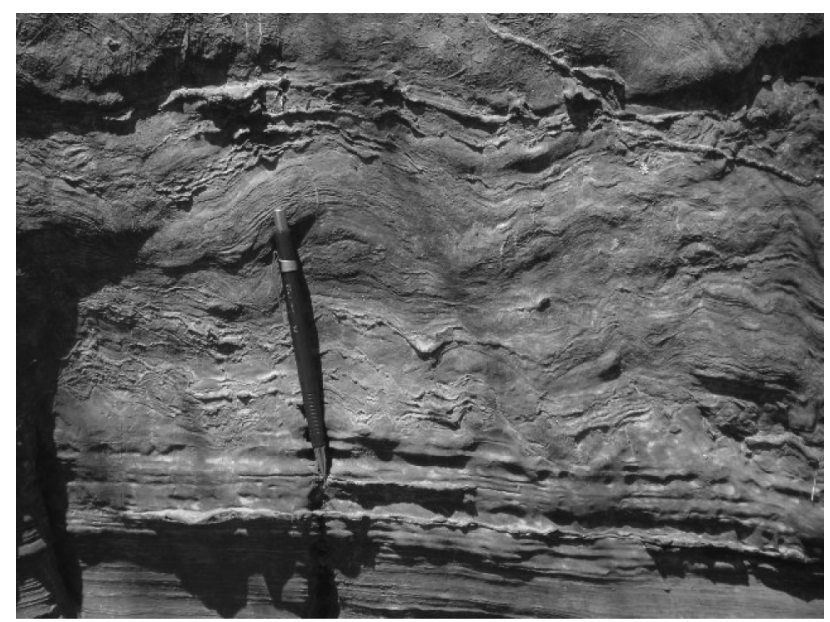

Figure 6-Exposure of the carbonate facies of the Sete Lagoas Formation, with laminated micritic limestone transitioning to lamellar breccia.

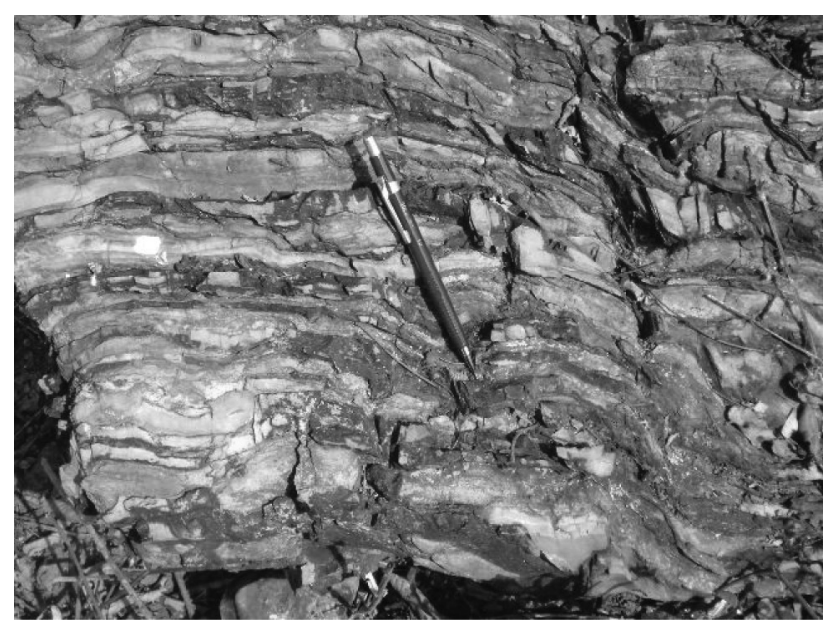

Figure 7 - Rock of the transition zone between pure limestone lenses and pelitic facies, composed of rhythmite characterized by regular intercalations of limestone with marlstone layers.

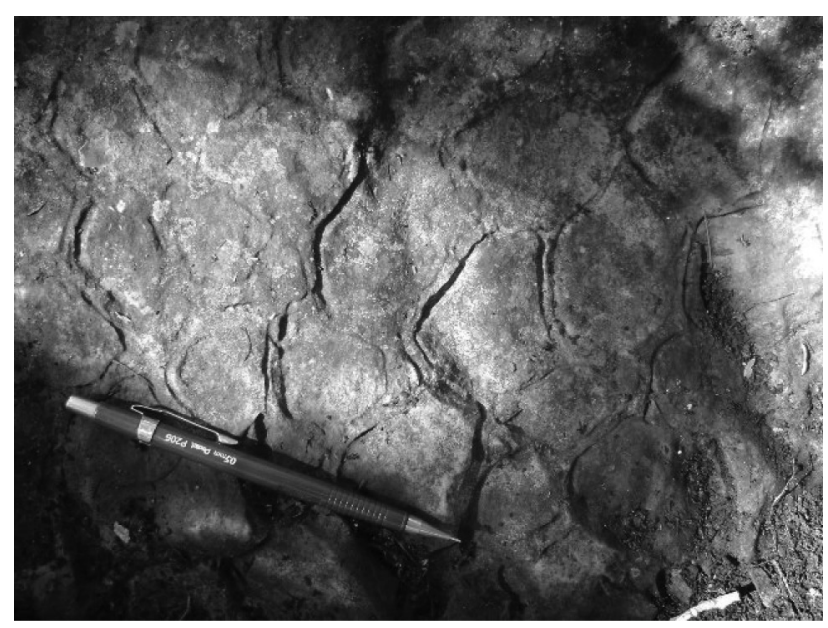

Figure 8-Mud cracks in the micritic limestone facies of the Sete Lagoas Formation. 
DISCUSSION AND CONCLUSIONS The sedimentation of the Psammo-pelitic-carbonate Unit is considered to have been greatly influenced by the bottom paleogeography and corresponds to the final regression related to the filling of the Paranoá Basin. In this context, the carbonate sediments were deposited in the shoal under warm, clean and shallower water conditions, and controlled by chemical precipitation of micrit muds. Carbonate deposits with intraclasts show micrit limestone reworking. Carbonate lenses, when more restricted, underwent eodiagenetic dolomitization. The occurrence of stromatolites also indicates a shallow-water origin for the carbonates, with water depth of up to approximately 20 meters for the development of conical forms or even shallower water for the development of columnar forms.

Pelites were deposited in deeper waters, below the wave base, undergoing vertical aggradation of muds. A high proportion of pelites indicates that the source areas were worn down and the deposition occurred in deeper waters, equivalent to infratidal zone.

Quartzites are interpreted as deposits of bottom channels that apparently cut the mixed platform in different directions. High roundness and sphericity indicate that the material was resedimented, which is a possible result of coarse-grained sediment reworking by traction currents in channelized environments. It is very common to have an organic pellicle surrounding the grains, which is compatible with the reducing conditions that can be reached in deeper channels in the shoals of tidally dominated platforms.

The deposition of the Sete Lagoas Formation occurred under conditions similar to those of the Psammo-pelitic-carbonate Unit, although the paleorelief that controlled the depositional processes was more accentuated. The paleogeography was formed above a post-glacial erosion surface, which resulted in a greater amplitude of the relief in the raised and lowered blocks that are more contrasting and more easily to be distinguished. In this environment, the large limestone lenses were deposited under more favorable conditions.

In both units, there are marl rocks in the transition zone from carbonate lenses to terrigenous facies. Pelitic marls occur in two ways: as rhythmites characterized by regular intercalation of pure limestones with marls, or as massive to stratified layers of marlstone. These facies are important since they show the lateral intercalation and the competition during the simultaneous deposition of carbonates and terrigenous.

The paleogeography represented by the great amplitude of the relief is very clear in marginal parts of the Bambuí basin, and it is very well represented in the regions of Campos Belos and São Domingos.

Another contrast between the mixed carbonate-siliciclastic sedimentation at the top of the Paranoá Group and the base of the Bambuí Group is the relief of the terrigenous source areas. Faciology and petrographic analyses of each unit show that the source area of the Paranoá Group was represented by granitic basement, which, at least in part, had an accentuated relief (high occurrence of microcline in the coarse-grained quartzite framework). The source area of the Sete Lagoas Formation was more worn down and flattened, which can be evidenced by the absence of psammites in this succession.

Fig. 9 schematically shows the depositional context for each unit and the main differences are: greater average depth of water in the mixed platform of the Paranoá Group, more stable and larger shoals in the mixed platform of the Bambui Group, channels of sedimentation of psammites only in the Paranoá Group, and more flattened source area in the Sete Lagoas Formation when compared to the Psammo-pelitic-carbonate Unit.

In summary, the deposition at the top unit of the Paranoá Group occurred in a mixed ramp controlled by the paleogeography (occurrence of shoals) in a passive margin during a regressive cycle. The deposition of the Bambuí Group occurred in a mixed platform with tidal shoals and raised areas occupied by carbonates which were sometimes subaerially exposed (mud cracks, lamellar breccias and teepees) under post-glaciogenic transgressive conditions. The relief with shoals coincides with the erosion surface (unconformity) that separates the Paranoá Group from the Bambuí Group. 

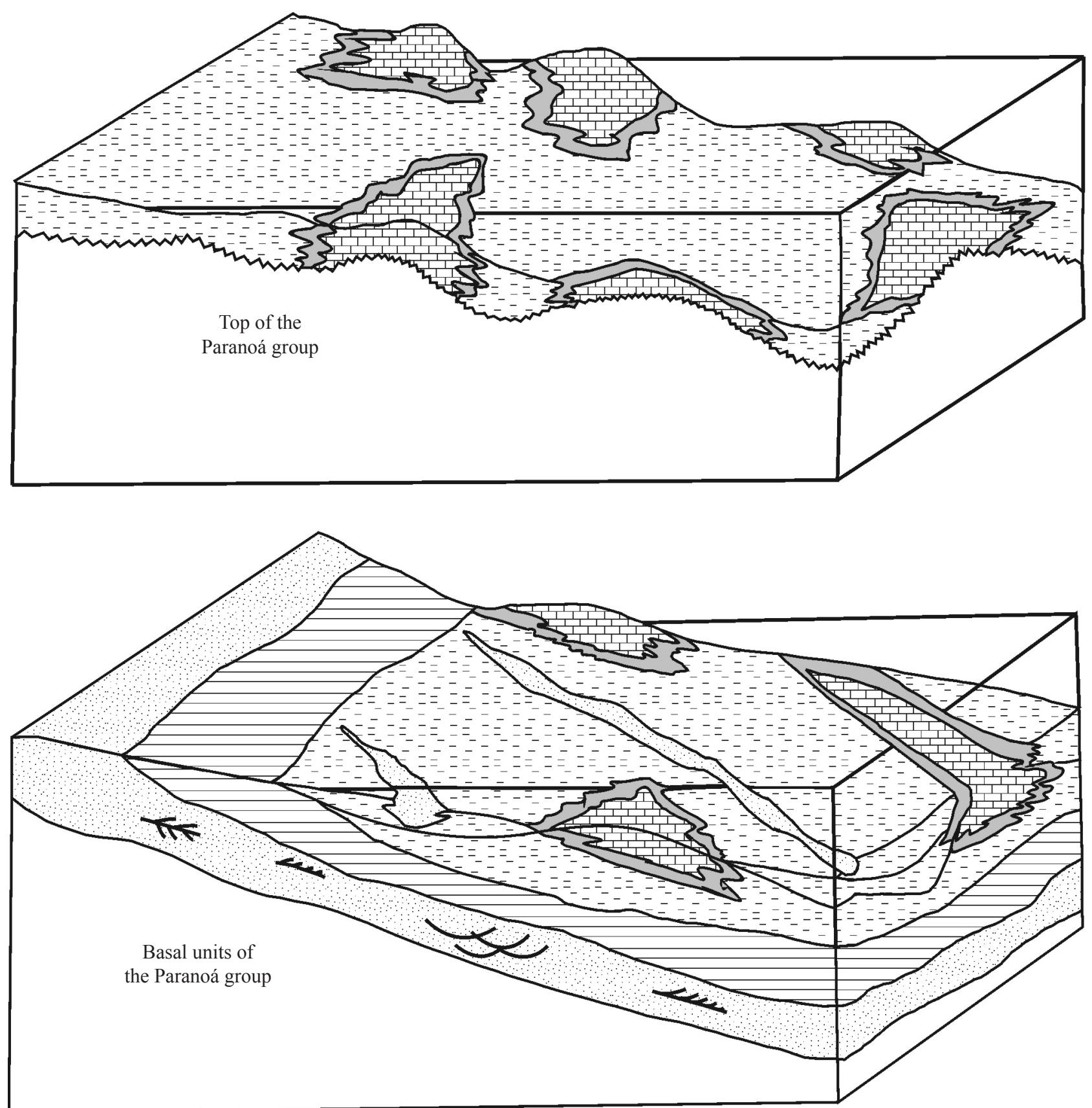

Figure 9 -Schematic models of sedimentation of mixed platforms at the top of the Paranoa Group and base of the Bambui Group.

\section{References}

Cózar P., Somerville I.D., Rodríguez S., Mas R., Medina-Varea P. 2006. Development of a late Viséan (Mississippian) mixed carbonate/siliciclastic platform in the Guadalmellato Valley (southwestern Spain). Sedimentary Geology, 183:269-295.

Dardenne M.A. 1978. Zonação tectônica na borda ocidental do Cráton São Francisco. In: An. $30^{\circ}$ Cong. Bras.Geol., Recife, SBG, vol.1, p. 299-308.

Dardenne M.A. 1979. Les minéralisations de plomb, zinc, fluor du Protérozoïque Supérieur dans le Brésil
Central. Tese de Doutorado, Universidade de Paris VI, Paris, $251 \mathrm{p}$.

Dardenne, M.A. 2000. The Brasilia Fold Belt. In: Cordani U.G., Milani E.J., Thomaz Filho D., Campos D.A. (ed.) Tectonic evolution of South America. Rio de Janeiro, International Geological Congress. p. 231-263.

Dardenne M.A., Melo S.M.G., Moeri, F. 1972. Conophyton: um fóssil index do Pré-Cambriano no Grupo Bambuí. Ciência e Cultura, 24:231-240.

Dorsey R.J. \& Kidwell S.M. 1999. Mixed carbonate- 
siliciclastic sedimentation on a tectonically active margin: example from the Pliocene of Baja California Sur, Mexico. Geology, 27(10):935-938.

Eyles N. \& Eyles C.H. 1992. Glacial depositional systems. In: Walker R.G. \& James N.P. (ed.). Facies models, response to sea level change. Geological Association of Canada. Stittsville, Ontario. p. 73-100.

Faria A. 1995. Estratigrafia e sistemas deposicionais do Grupo Paranoá nas áreas de Cristalina, Distrito Federal e São João D’Aliança - Alto Paraíso de Goiás. Tese de Doutorado, Universidade de Brasília, Brasília, 199p.

Freitas-Silva F.H. \& Campos J.E.G. 1998. Geologia do Distrito Federal. In: Inventário hidrogeológico e dos recursos hídricos superficiais do Distrito Federal. Parte I. Brasília, IEMA-SEMATEC/Universidade de Brasília, p. 1-86.

Freitas-Silva H.F. 1996. Metalogênese do depósito do Morro do Ouro, Paracatu - MG. Brasília. Tese de Doutorado, Universidade de Brasília, Brasília, 338 p. (Unpublished).

Fuck R.A., Marini J.O., Dardenne M.A., Figueiredo A.N. 1988. Coberturas metassedimentares do Proterozóico Médio: os grupos Araí e Paranoá na região de Niquelândia-Colinas, Goiás. Revista Brasileira de Geociências, 18(1):54-62.

Guimarães E.M. 1997. Estudos de proveniência e diagênese com ênfase na caracterização dos filossilicatos dos grupos Paranoá e Bambuí na região de Bezerra-
Cabeceiras, Goiás. Tese de Doutorado, Universidade de Brasília, Brasília, 269 p.

Khetani B. \& Read J.F. 2002. Sequence development of a mixed carbonate-siliciclastic high-relief ramp, Mississippian, Kentucky, USA. Sedimentary Geology, 72(5):657-672.

Laranjeira N.P.F. 1992. Geologia do Grupo Paranoá na região de Unaí: uma plataforma siliciclásticacarbonática no Proterozóico de Minas Gerais. Dissertação de Mestrado, Universidade de Brasília, Brasília, 213 p. (Unpublished).

Martins F.A.L. 1999. Análise faciológica e estratigráfica do paleo-mesoproterozóico: Seqüência Araí no Parque Nacional da Chapada dos Veadeiros, Goiás. Dissertação de Mestrado, Universidade de Brasília, Brasília, 137 p.

Rowe C.E. 2002. The Cunningham Formation: a mixed carbonate/siliciclastic ramp in the terminal Proterozoic of Western Canadá. In: The Geological Society of America.Denver Annual Meeting. Paper 222-1.

Spalletti L.A., Franzese J.R., Matheos S.D., Schuarz E. 2000. Sequence stratigraphy of a tidally dominated carbonate-siliciclastic ramp; the Tithonian Early Berriasian of the Southern Neuquén Basin, Argentina. Journal of the Geological Society, 157:433-446.

Manuscrito 15157

Recebido em: 24/08/2009

Aprovado em: 24/04/2012 